\title{
GENETICS, SURNAMES, GRANDPARENTS' NATIONALITIES, AND ETHNIC ADMIXTURE IN SOUTHERN BRAZIL - DO THE PATTERNS OF VARIATION COINCIDE?
}

\author{
C.L. Dornelles ${ }^{l}$, S.M. Callegari-Jacques ${ }^{1,2}$, W.M. Robinson ${ }^{l}$, T.A. Weimer', M.H.L.P. Franco ${ }^{1}$, A.C. Hickmann ${ }^{l}$, \\ C.J. Geiger ${ }^{l}$ and F.M. Salzano ${ }^{l}$
}

\begin{abstract}
A total of 2,708 individuals from the European-derived population of Rio Grande do Sul, divided into seven mesoregions, and of 226 individuals of similar origin from Santa Catarina were studied. Seventeen protein genetic systems, as well as grandparents' nationalities, individuals' surnames, and interethnic admixture were investigated. The alleles which presented the highest and lowest differences were GLO1`2 (16\%) and PGD*A (2\%), respectively, but in general no significant genetic differences were found among mesoregions. The values observed were generally those expected for individuals of European descent, with the largest difference being a lower prevalence (34-39\%) of $\mathbf{P}^{\star} \mathbf{1}$. Significant heterogeneity among mesoregions was observed for the other variables considered, and was consistent with historical records. The Amerindian contribution to the gene pool of European-derived subjects in Rio Grande do Sul was estimated to be as high as $11 \%$. Based on the four data sets, the most general finding was a tendency for a northeast-southwest separation of the populations studied. Seven significant phenotype associations between systems were observed at the $5 \%$ level (three at the $0.1 \%$ level). Of the latter, the two most interesting (since they were also observed in other studies) were MNSs/Duffy and Rh/ACP.
\end{abstract}

\section{INTRODUCTION}

The non-Indian populations of the States of Rio Grande do Sul and Santa Catarina have been fairly well studied in the last three decades (Tondo and Salzano, 1962; Tondo et al., 1963; Salzano, 1963; Schwantes et al., 1967; Salzano et al., 1967, 1968a,b; Lewgoy and Salzano, 1968; Hutz et al., 1977; Weimer et al., 1981, 1987, 1993; Franco et al., 1981, 1982, 1986; Silva et al., 1981; Franco and Salzano, 1985; Rieger et al., 1988; Arai et al., 1989; Bortolini et al., 1992, 1994, 1995, 1997 a,b, 1998; Heidrich et al., 1995; Robinson et al., 1998). However, these investigations have not provided a detailed distribution pattern of the polymorphisms investigated, nor a comparison with attributes such as grandparents' nationalities or the individuals' surnames, which could give clues about the history of these groups. Ethnic admixture was evaluated using dihybrid (European/African-derived) models only. In addition, genetic diversity measures were seldom employed, and the relationships between markers in different genetic systems rarely considered. Over the years, we have collected a large amount of information during paternity determinations in these populations. These data include 17 protein genetic systems studied in about 3,000 European-derived subjects living in the States of Rio Grande do Sul and Santa Catarina. Analysis of these results showed that despite a general homogeneity, there was a tendency

\footnotetext{
${ }^{I}$ Departamento de Genética, Instituto de Biociências, Universidade Federal do Rio Grande do Sul, Caixa Postal 15053, 91501-970 Porto Alegre, RS, Brasil. Send correspondence to F.M.S. E-mail: salzano@if1.if.ufrgs.br ${ }^{2}$ Departamento de Estatística, Instituto de Matemática, Universidade $\mathrm{Fe}$ deral do Rio Grande do Sul, Campus do Vale, 91501-970 Porto Alegre, RS, Brasil.
}

towards a northeast-southwest division. Three significant associations between systems were detected, and the Amerindian contribution to the gene pool of people from Rio Grande do Sul phenotypically classified as white was estimated to be as high as $11 \%$.

\section{SUBJECTS AND METHODS}

The data used in this analysis were obtained in 1617 cases of paternity determinations performed in our Department between 1962 and 1996. Only European-derived, unrelated subjects were considered, and some of the subjects investigated in the early part of the study were excluded because the determinations did not include the full set of systems finally established. Non-Caucasian individuals were omitted from the analysis because they were few in number.

The 17 genetic systems investigated and the references for the methods of determination employed are listed in Table I.

For the analysis, the samples from the State of Rio Grande do Sul were grouped according to the seven mesoregions proposed by the Brazilian Institute of Geography and Statistics (IBGE, 1991), namely northwest (NW), northeast (NE), center-west (CW), center-east (CE), metropolitan Porto Alegre (MPOA), southwest (SW), and southeast (SE). They are indicated on the maps in Figures 1-4. Since the number of individuals studied living in Santa Catarina (SC) was much smaller, this sample was not divided into regions.

Frequencies of the phenotypes, alleles, grandparents' nationalities, and individuals' surnames were obtained using the SPSS ${ }^{\mathrm{TM}}$ (Anonymous, 1992) and MAXLIK (Reed and Schull, 1968) programs. Heterogeneity among mesoregions was analyzed by chi-square tests using the PEPI program (Gahlinger and Abramson, 1995). $\mathrm{D}_{\mathrm{A}}$ dis- 
Table I - Genetic systems and laboratory methods employed in the present study.

\begin{tabular}{|lll|}
\hline Method & Systems & References \\
\hline Starch gel electrophoresis & Acid phosphatase (ACP) & Harris and Hopkinson (1976) \\
& Adenylate kinase (AK) & Fildes and Harris (1966); Spencer et al. (1968) \\
& Albumin (ALB) ${ }^{1}$ & Kueppers and Bearn (1966) \\
& Ceruloplasmin (CP) & Bowman and Bearn (1965) \\
& Esterase D (ESD) & Harris and Hopkinson (1976) \\
& Glucose-6-phosphate dehydrogenase (G6PD) & Fildes and Parr (1963) \\
& Haptoglobin (HP) & Poulik (1957) \\
& Phosphoglucomutase (PGM1, PGM2) & Spencer et al. (1964); Blake and Omoto (1975) \\
& Phosphogluconate dehydrogenase (PGD) & Fildes and Parr (1963) \\
& Transferrin (TF) & Poulik (1957); Bowman and Bearn (1965); \\
Agarose starch electrophoresis & Geserick et al. (1968) \\
& Glyoxalase 1 (GLO1) & Rieger et al. (1988); Parr et al. (1977) \\
& ABO ${ }^{3}$ & Dunsford and Bowley (1967) \\
Immunological & Duffy (FY) & \\
& MNSs & \\
& P & \\
& RH & \\
\hline
\end{tabular}

${ }^{1}$ To confirm variants: Weitkamp et al. (1967); ${ }^{2}$ Typing by isoelectric focusing was performed according to Yuasa et al. (1986); ${ }^{3} \mathrm{~A}$ subtypes were identified using Ulex europaeus extract (Boyd and Shapleigh, 1954).

tances were calculated as indicated in Nei et al. (1983) and Nei and Roychoudhury (1993). The corresponding dendrograms were obtained by UPGMA (unweighted pairgroup method with arithmetic mean; Sneath and Sokal, 1973), and the reliability of the trees evaluated by the bootstrap test using 2,000 replications (Hedges, 1992). All these calculations were done using the DISPAN program (Ota, 1993). The same distances were used for a principal coordinate analysis using the NTSYS program (Rohlf, 1987).

The congruence between the matrices obtained for the genetic, nationality, surname, and admixture frequencies was evaluated by Mantel's (1967) method, using NTSYS and a DOS program kindly provided by J.C. Long.

Association between phenotypes, considering the different systems, was evaluated by chi-square tests. When more than $20 \%$ of the numbers showed less than five values, the method of Roff and Bentzen (1989) was employed. Correction for the large number (52) of comparisons made was obtained by dividing the formal $5 \%$ level by this number (Fañanás et al., 1997). The degree of intra- and interpopulation variability was evaluated using Nei's (1973, 1986, 1987) statistics and the DISPAN program.

Estimates of interethnic admixture were calculated by the gene identity method (Chakraborty, 1985) using the ADMIX program kindly provided by this author. Parental allele frequencies were estimated by weighted averages of the data compiled by Mourant et al. (1976), Tills et al. (1983), Roychoudhury and Nei (1988), Bortolini et al. (1995), and Salzano et al. (1997).

\section{RESULTS}

Table II presents the allele frequencies for the 17 genetic systems studied in the seven mesoregions of Rio
Grande do Sul and in Santa Catarina (phenotype frequencies are too extensive to be shown here, but can be supplied on request). The albumin, ceruloplasmin, phosphoglucomutase 2 and transferrin loci presented very restricted variability, while the remaining 13 loci showed nonsignificant variations among regions. The largest dissimilarity occurred with the GLO1*2 allele of the glyoxalase 1 system, which showed a frequency of $47 \%$ in the CenterWest region of Rio Grande do Sul and 63\% in Santa Catarina. The values were generally those expected for an European-derived population, the average deviation from a putative parental group (which included Portuguese, Italians, Germans and Spaniards) being only $4 \%$ for all of Rio Grande do Sul, and 3\% for Santa Catarina. The largest deviation was observed for $\mathbf{P}^{*} \mathbf{1}$ of the $\mathrm{P}$ blood group, which had an average prevalence of $39 \%$ in Rio Grande do Sul and 34\% in Santa Catarina; the frequency in the reference population was $53 \%$.

There was little genetic diversity among the mesoregions, with the average heterozygosity varying between 30 and $32 \%$. Total variability $\left(\mathrm{H}_{\mathrm{T}}\right)$ was calculated as 0.309 , only $0.6 \%$ of which was attributable to differences among mesoregions.

The distribution of the grandparents' nationalities is given in Table III. As expected, grandparents of Brazilian nationality were the most frequent in all regions, but their prevalence varied from $78 \%$ in the NE to $94 \%$ in the CE. Grandparents of Italian nationality were the second most common in five of the eight mesoregions (with frequencies varying from $2 \%$ in the SW to $19 \%$ in the NE), with German in two ( $4 \%$ in the $\mathrm{CW}$ and the $\mathrm{CE}$ ), and Portuguese in one (3\% in the SE). The heterogeneity among mesoregions proved to be statistically highly significant. 
Table II - Allele frequencies for the 17 genetic systems studied in seven mesoregions of the State of Rio Grande do Sul (RS) and in Santa Catarina (SC) ${ }^{1}$.

\begin{tabular}{|c|c|c|c|c|c|c|c|c|c|c|}
\hline \multirow{2}{*}{$\begin{array}{l}\text { Genetic systems } \\
\text { and alleles } \\
\text { or haplotypes }\end{array}$} & \multicolumn{10}{|c|}{ Mesoregions $^{2}$} \\
\hline & NW & $\mathrm{NE}$ & $\mathrm{CW}$ & $\mathrm{CE}$ & MPOA & SW & $\mathrm{SE}$ & Total RS & $\mathrm{SC}$ & Total \\
\hline \multicolumn{11}{|l|}{ ABO } \\
\hline A1 & 0.202 & 0.167 & 0.226 & 0.205 & 0.192 & 0.193 & 0.239 & 0.199 & 0.216 & 0.196 \\
\hline A2 & 0.071 & 0.059 & 0.040 & 0.074 & 0.057 & 0.064 & 0.052 & 0.057 & 0.053 & 0.061 \\
\hline B & 0.072 & 0.057 & 0.106 & 0.082 & 0.069 & 0.063 & 0.103 & 0.071 & 0.060 & 0.070 \\
\hline $\mathbf{O}$ & 0.655 & 0.717 & 0.628 & 0.639 & 0.682 & 0.680 & 0.606 & 0.673 & 0.671 & 0.673 \\
\hline N. ${ }^{\circ}$ studied & 684 & 298 & 50 & 176 & 1261 & 172 & 67 & 2708 & 224 & 2932 \\
\hline \multicolumn{11}{|l|}{$\mathbf{A C P}$} \\
\hline A & 0.291 & 0.277 & 0.308 & 0.304 & 0.277 & 0.299 & 0.280 & 0.285 & 0.330 & 0.288 \\
\hline B & 0.664 & 0.669 & 0.671 & 0.646 & 0.685 & 0.660 & 0.652 & 0.672 & 0.606 & 0.667 \\
\hline C & 0.045 & 0.054 & 0.021 & 0.050 & 0.038 & 0.041 & 0.068 & 0.043 & 0.064 & 0.045 \\
\hline N. ${ }^{\circ}$ studied & 682 & 296 & 47 & 171 & 1211 & 169 & 66 & 2642 & 226 & 2868 \\
\hline \multicolumn{11}{|l|}{ ALB } \\
\hline A & 0.999 & 1.000 & 1.000 & 0.997 & 1.000 & 1.000 & 1.000 & 0.999 & 1.000 & 0.999 \\
\hline V & 0.001 & 0.000 & 0.000 & 0.003 & 0.000 & 0.000 & 0.000 & 0.001 & 0.000 & 0.001 \\
\hline N. ${ }^{\circ}$ studied & 680 & 288 & 48 & 174 & 1237 & 170 & 67 & 2664 & 226 & 2890 \\
\hline \multicolumn{11}{|l|}{ AK } \\
\hline 1 & 0.970 & 0.970 & 0.988 & 0.985 & 0.979 & 0.970 & 0.948 & 0.974 & 0.978 & 0.974 \\
\hline 2 & 0.029 & 0.029 & 0.012 & 0.015 & 0.021 & 0.030 & 0.045 & 0.025 & 0.022 & 0.025 \\
\hline 3 & 0.001 & 0.001 & 0.000 & 0.000 & $<0.001$ & 0.000 & 0.007 & 0.001 & 0.000 & 0.001 \\
\hline N. ${ }^{\circ}$ studied & 668 & 287 & 41 & 171 & 1205 & 170 & 66 & 2608 & 226 & 2834 \\
\hline \multicolumn{11}{|l|}{ CP } \\
\hline $\mathbf{A}$ & 0.001 & 0.000 & 0.000 & 0.000 & 0.002 & 0.000 & 0.000 & 0.001 & 0.000 & 0.001 \\
\hline B & 0.999 & 1.000 & 1.000 & 1.000 & 0.997 & 1.000 & 1.000 & 0.998 & 1.000 & 0.999 \\
\hline V & 0.000 & 0.000 & 0.000 & 0.000 & 0.001 & 0.000 & 0.000 & 0.001 & 0.000 & $<0.001$ \\
\hline N. ${ }^{\circ}$ studied & 682 & 288 & 48 & 174 & 1241 & 168 & 67 & 2668 & 226 & 2894 \\
\hline \multicolumn{11}{|l|}{ ESD } \\
\hline 1 & 0.852 & 0.853 & 0.878 & 0.857 & 0.855 & 0.837 & 0.828 & 0.853 & 0.858 & 0.853 \\
\hline 2 & 0.147 & 0.147 & 0.122 & 0.143 & 0.145 & 0.163 & 0.172 & 0.147 & 0.142 & 0.147 \\
\hline 3 & 0.001 & 0.000 & 0.000 & 0.000 & 0.000 & 0.000 & 0.000 & 0.000 & 0.000 & 0.000 \\
\hline N. ${ }^{\circ}$ studied & 682 & 279 & 45 & 171 & 1164 & 166 & 64 & 2571 & 226 & 2797 \\
\hline \multicolumn{11}{|l|}{ DUFFY } \\
\hline $\mathbf{A}$ & 0.291 & 0.316 & 0.175 & 0.275 & 0.272 & 0.310 & 0.304 & 0.283 & 0.242 & 0.279 \\
\hline A- & 0.709 & 0.684 & 0.825 & 0.725 & 0.728 & 0.690 & 0.696 & 0.717 & 0.758 & 0.721 \\
\hline N. ${ }^{\circ}$ studied & 677 & 286 & 50 & 175 & 1225 & 168 & 64 & 2645 & 226 & 2871 \\
\hline \multicolumn{11}{|l|}{ GLO1 } \\
\hline 1 & 0.446 & 0.401 & 0.533 & 0.415 & 0.416 & 0.373 & 0.437 & 0.422 & 0.369 & 0.418 \\
\hline 2 & 0.554 & 0.599 & 0.467 & 0.585 & 0.584 & 0.627 & 0.563 & 0.578 & 0.631 & 0.582 \\
\hline N. ${ }^{\circ}$ studied & 680 & 279 & 45 & 171 & 1153 & 165 & 64 & 2557 & 225 & 2782 \\
\hline \multicolumn{11}{|l|}{ G6PD (males) } \\
\hline A & 0.006 & 0.000 & 0.000 & 0.020 & 0.009 & 0.000 & 0.026 & 0.003 & 0.009 & 0.008 \\
\hline A- & 0.003 & 0.007 & 0.000 & 0.000 & 0.003 & 0.000 & 0.000 & 0.008 & 0.000 & 0.003 \\
\hline B & 0.985 & 0.980 & 1.000 & 0.980 & 0.984 & 1.000 & 0.974 & 0.985 & 0.982 & 0.984 \\
\hline Med & 0.006 & 0.000 & 0.000 & 0.000 & 0.002 & 0.000 & 0.000 & 0.002 & 0.000 & 0.002 \\
\hline V & 0.000 & 0.013 & 0.000 & 0.000 & 0.002 & 0.000 & 0.000 & 0.002 & 0.009 & 0.003 \\
\hline N. ${ }^{\circ}$ studied & 338 & 148 & 25 & 88 & 579 & 79 & 39 & 1296 & 113 & 1409 \\
\hline \multicolumn{11}{|l|}{ G6PD (females) } \\
\hline A & 0.015 & 0.011 & 0.045 & 0.000 & 0.011 & 0.018 & 0.020 & 0.013 & 0.013 & 0.013 \\
\hline A- & 0.000 & 0.004 & 0.000 & 0.000 & 0.006 & 0.012 & 0.000 & 0.004 & 0.004 & 0.004 \\
\hline B & 0.985 & 0.985 & 0.955 & 1.000 & 0.980 & 0.964 & 0.980 & 0.981 & 0.979 & 0.981 \\
\hline Med & 0.000 & 0.000 & 0.000 & 0.000 & 0.001 & 0.000 & 0.000 & $<0.001$ & 0.000 & $<0.001$ \\
\hline V & 0.000 & 0.000 & 0.000 & 0.000 & 0.002 & 0.000 & 0.000 & 0.001 & 0.004 & 0.001 \\
\hline N. ${ }^{\circ}$ studied & 330 & 135 & 22 & 84 & 570 & 83 & 25 & 1249 & 113 & 1362 \\
\hline \multicolumn{11}{|l|}{$\mathbf{H P}$} \\
\hline 1 & 0.429 & 0.408 & 0.398 & 0.454 & 0.444 & 0.447 & 0.470 & 0.437 & 0.409 & 0.434 \\
\hline 2 & 0.570 & 0.592 & 0.602 & 0.543 & 0.556 & 0.550 & 0.530 & 0.562 & 0.591 & 0.565 \\
\hline $\mathbf{V}$ & 0.001 & 0.000 & 0.000 & 0.003 & 0.000 & 0.003 & 0.000 & 0.001 & 0.000 & $<0.001$ \\
\hline N. ${ }^{\circ}$ studied & 685 & 294 & 49 & 176 & 1254 & 170 & 67 & 2695 & 226 & 2921 \\
\hline
\end{tabular}


Table II - Continued

\begin{tabular}{|c|c|c|c|c|c|c|c|c|c|c|}
\hline \multirow{2}{*}{$\begin{array}{l}\text { Genetic systems } \\
\text { and alleles } \\
\text { or haplotypes }\end{array}$} & \multicolumn{10}{|c|}{ Mesoregions $^{2}$} \\
\hline & NW & $\mathrm{NE}$ & $\mathrm{CW}$ & $\mathrm{CE}$ & MPOA & SW & SE & Total RS & $\mathrm{SC}$ & Total \\
\hline \multicolumn{11}{|l|}{ MNSs } \\
\hline MS & 0.205 & 0.225 & 0.168 & 0.176 & 0.199 & 0.210 & 0.183 & 0.202 & 0.205 & 0.203 \\
\hline Ms & 0.401 & 0.366 & 0.374 & 0.351 & 0.355 & 0.398 & 0.357 & 0.371 & 0.337 & 0.367 \\
\hline NS & 0.095 & 0.052 & 0.092 & 0.081 & 0.094 & 0.098 & 0.111 & 0.089 & 0.076 & 0.088 \\
\hline Ns & 0.299 & 0.357 & 0.366 & 0.392 & 0.352 & 0.294 & 0.349 & 0.338 & 0.382 & 0.342 \\
\hline N. ${ }^{o}$ studied & 667 & 274 & 48 & 167 & 1200 & 167 & 63 & 2586 & 226 & 2812 \\
\hline \multicolumn{11}{|l|}{$\mathbf{P}$} \\
\hline 1 & 0.372 & 0.418 & 0.409 & 0.350 & 0.384 & 0.444 & 0.432 & 0.387 & 0.339 & 0.383 \\
\hline 1- & 0.628 & 0.582 & 0.591 & 0.650 & 0.616 & 0.556 & 0.568 & 0.613 & 0.661 & 0.617 \\
\hline N. ${ }^{\circ}$ studied & 637 & 275 & 43 & 161 & 1192 & 155 & 62 & 2525 & 213 & 2738 \\
\hline \multicolumn{11}{|l|}{ PGD } \\
\hline $\mathbf{A}$ & 0.982 & 0.978 & 0.989 & 0.974 & 0.975 & 0.975 & 0.969 & 0.977 & 0.978 & 0.977 \\
\hline $\mathbf{C}$ & 0.017 & 0.022 & 0.011 & 0.026 & 0.025 & 0.025 & 0.031 & 0.022 & 0.022 & 0.022 \\
\hline $\mathbf{R}$ & 0.001 & 0.000 & 0.000 & 0.000 & 0.000 & 0.000 & 0.000 & 0.001 & 0.000 & $<0.001$ \\
\hline N. ${ }^{o}$ studied & 672 & 281 & 47 & 172 & 1163 & 163 & 65 & 2563 & 226 & 2789 \\
\hline \multicolumn{11}{|l|}{ PGM1 } \\
\hline 1 & 0.771 & 0.718 & 0.685 & 0.692 & 0.745 & 0.729 & 0.823 & 0.745 & 0.709 & 0.744 \\
\hline 2 & 0.229 & 0.279 & 0.315 & 0.308 & 0.255 & 0.271 & 0.177 & 0.254 & 0.291 & 0.256 \\
\hline 7 & 0.000 & 0.003 & 0.000 & 0.000 & 0.000 & 0.000 & 0.000 & 0.001 & 0.000 & $<0.001$ \\
\hline N..$^{\circ}$ studied & 385 & 165 & 27 & 91 & 854 & 98 & 48 & 1668 & 98 & 1766 \\
\hline \multicolumn{11}{|c|}{ PGM1 (isoelectric focusing) } \\
\hline $\mathbf{1 A}$ & 0.568 & 0.623 & 0.525 & 0.601 & 0.612 & 0.643 & 0.632 & 0.599 & 0.657 & 0.606 \\
\hline 1B & 0.167 & 0.130 & 0.200 & 0.161 & 0.131 & 0.147 & 0.105 & 0.147 & 0.138 & 0.145 \\
\hline $\mathbf{2 A}$ & 0.187 & 0.194 & 0.200 & 0.202 & 0.192 & 0.147 & 0.184 & 0.189 & 0.134 & 0.183 \\
\hline $2 B$ & 0.078 & 0.053 & 0.075 & 0.036 & 0.065 & 0.063 & 0.079 & 0.065 & 0.071 & 0.066 \\
\hline N..$^{\circ}$ studied & 301 & 131 & 20 & 84 & 385 & 71 & 19 & 1011 & 128 & 1139 \\
\hline \multicolumn{11}{|l|}{ PGM2 } \\
\hline 1 & 0.999 & 1.000 & 1.000 & 1.000 & 0.999 & 1.000 & 1.000 & 0.999 & 1.000 & 0.999 \\
\hline 2 & 0.001 & 0.000 & 0.000 & 0.000 & 0.001 & 0.000 & 0.000 & 0.001 & 0.000 & 0.001 \\
\hline N. ${ }^{o}$ studied & 362 & 164 & 24 & 83 & 818 & 101 & 48 & 1600 & 80 & 1680 \\
\hline \multicolumn{11}{|l|}{$\mathbf{R h}$} \\
\hline DCE & 0.013 & 0.009 & 0.014 & $<0.001$ & 0.007 & 0.000 & $<0.001$ & 0.008 & 0.001 & 0.008 \\
\hline DCe & 0.405 & 0.401 & 0.399 & 0.379 & 0.402 & 0.483 & 0.369 & 0.405 & 0.419 & 0.406 \\
\hline DcE & 0.113 & 0.114 & 0.096 & 0.129 & 0.135 & 0.134 & 0.097 & 0.125 & 0.113 & 0.124 \\
\hline Dce & 0.095 & 0.046 & 0.064 & 0.038 & 0.093 & 0.097 & 0.106 & 0.083 & 0.081 & 0.083 \\
\hline dCE & 0.000 & 0.000 & 0.000 & 0.000 & 0.000 & 0.000 & 0.000 & 0.000 & 0.006 & $<0.001$ \\
\hline dCe & 0.020 & 0.028 & 0.048 & 0.025 & 0.028 & $<0.001$ & 0.019 & 0.024 & 0.012 & 0.024 \\
\hline dcE & 0.012 & 0.009 & 0.000 & 0.007 & 0.007 & 0.000 & 0.000 & 0.008 & 0.006 & 0.008 \\
\hline dce & 0.342 & 0.393 & 0.379 & 0.422 & 0.328 & 0.286 & 0.409 & 0.347 & 0.362 & 0.347 \\
\hline N. ${ }^{\circ}$ studied & 685 & 297 & 50 & 176 & 1260 & 171 & 67 & 2706 & 226 & 2932 \\
\hline \multicolumn{11}{|l|}{ TF } \\
\hline B & 0.002 & 0.000 & 0.000 & 0.006 & 0.001 & 0.000 & 0.000 & 0.001 & 0.000 & 0.001 \\
\hline C & 0.997 & 1.000 & 1.000 & 0.994 & 0.999 & 1.000 & 1.000 & 0.998 & 1.000 & 0.999 \\
\hline D & 0.001 & 0.000 & 0.000 & 0.000 & 0.000 & 0.000 & 0.000 & 0.001 & 0.000 & $<0.001$ \\
\hline N. ${ }^{\circ}$ studied & 684 & 292 & 48 & 174 & 1240 & 170 & 67 & 2675 & 226 & 2901 \\
\hline
\end{tabular}

${ }^{1}$ To simplify the table, rare variants were grouped under the letter V. Their names are as follows: (a) albumin - NW mesoregion: Passo Fundo, CE: Vera Cruz (Franco et al., 1998); (b) ceruloplasmin - Porto Alegre (Franco et al., 1981); (c) G6PD - NE: Seattle and Farroupilha, MPOA: Seattle, SW: São Borja, SC: Seattle and Lages (Weimer et al., 1993, 1998); (d) Haptoglobin - not studied in detail and therefore no definite nomenclature should be applied.

${ }^{2}$ NW: Northwest; NE: Northeast; CW: Center-West; CE: Center-East; MPOA: Metropolitan Porto Alegre; SW: Southwest; SE: Southeast; RS: Rio Grande do Sul; SC: Santa Catarina. 
Table III - Distribution (\%) of the grandparents' nationalities of individuals living in the seven mesoregions of the State of Rio Grande do Sul (RS) and in Santa Catarina (SC).

\begin{tabular}{|lrrrrrrrrr}
\hline \multirow{2}{*}{$\begin{array}{l}\text { Grandparents' } \\
\text { nationalities }\end{array}$} & \multicolumn{7}{c}{ Mesoregions $^{1}$} \\
\cline { 2 - 10 } & $\mathrm{NW}$ & $\mathrm{NE}$ & $\mathrm{CW}$ & $\mathrm{CE}$ & MPOA & SW & SE & RS & SC \\
\hline Argentinean & 0.1 & 0 & 0 & 0 & 0.1 & 0.4 & 0 & 0.1 & 0 \\
Brazilian & 89.0 & 77.5 & 90.4 & 94.1 & 89.3 & 93.4 & 93.2 & 88.6 & 92.8 \\
German & 3.2 & 0.9 & 4.3 & 4.3 & 3.1 & 0.7 & 0.8 & 2.8 & 2.3 \\
Italian & 6.0 & 18.9 & 3.2 & 1.0 & 3.7 & 2.4 & 0.4 & 5.6 & 3.9 \\
Polish & 0.9 & 1.0 & 0 & 0.6 & 0.9 & 0 & 0.4 & 0.8 & 0 \\
Portuguese & 0.2 & 1.0 & 1.1 & 0 & 0.7 & 0 & 3.2 & 0.6 & 0.4 \\
Uruguayan & $<0.1$ & 0 & 0.5 & 0 & 0.7 & 1.0 & 1.6 & 0.4 & 0 \\
Others & 0.6 & 0.7 & 0.5 & 0 & 1.5 & 2.1 & 0.4 & 1.1 & 0.6 \\
\hline Total & 2668 & 1164 & 188 & 684 & 4859 & 676 & 252 & 10491 & 876 \\
\hline
\end{tabular}

${ }^{1}$ Abbreviations as defined in Table II. $\chi^{2}=686.55$; d.f. $=49 ;(\mathrm{P} \pm \mathrm{SE})<(0.001 \pm 0.000)$ (Roff and Bentzen's (1989) method).

Table IV - Distribution (\%) of the surnames of individuals living in the seven mesoregions of the State of Rio Grande do Sul (RS) and in Santa Catarina (SC).

\begin{tabular}{|c|c|c|c|c|c|c|c|c|c|}
\hline \multirow[t]{2}{*}{ Surnames } & \multicolumn{9}{|c|}{ Mesoregions $^{1}$} \\
\hline & NW & NE & $\mathrm{CW}$ & $\mathrm{CE}$ & MPOA & SW & SE & $\mathrm{RS}$ & SC \\
\hline Arabian & 0.3 & 0 & 2.0 & 0 & 0.2 & 0.6 & 0 & 0.2 & 1.0 \\
\hline English & 0.7 & 1.0 & 0 & 1.1 & 1.0 & 0.6 & 1.5 & 0.9 & 0.5 \\
\hline French & 2.1 & 0.7 & 2.0 & 0.6 & 1.0 & 2.3 & 1.5 & 1.3 & 1.5 \\
\hline German & 16.7 & 5.8 & 22.5 & 35.6 & 16.1 & 5.8 & 10.4 & 15.7 & 12.0 \\
\hline Greek & 0.1 & 0 & 0 & 0 & 0.1 & 0 & 1.5 & 0.1 & 1.0 \\
\hline Italian & 30.7 & 50.5 & 10.2 & 16.7 & 13.6 & 13.4 & 10.4 & 22.0 & 32.0 \\
\hline Latin & 0.4 & 0 & 0 & 0.6 & 0.3 & 0 & 0 & 0.3 & 5.5 \\
\hline Polish & 3.4 & 1.3 & 0 & 0.6 & 2.0 & 0.6 & 0 & 2.0 & 4.5 \\
\hline Portuguese & 42.5 & 37.3 & 57.2 & 41.3 & 61.3 & 68.6 & 73.2 & 53.4 & 38.0 \\
\hline Spanish & 2.2 & 3.4 & 6.1 & 2.9 & 3.7 & 7.5 & 1.5 & 3.5 & 4.0 \\
\hline Others & 0.9 & 0 & 0 & 0.6 & 0.7 & 0.6 & 0 & 0.6 & 0 \\
\hline Total & 678 & 295 & 49 & 174 & 1256 & 172 & 67 & 2691 & 200 \\
\hline
\end{tabular}

${ }^{1}$ Abbreviations as defined in Table II. $\chi^{2}=340.68$; d.f. $=70 ;(\mathrm{P} \pm \mathrm{SE})<(0.001 \pm 0.000)$ (Roff and Bentzen's (1989) method).

Individuals with Portuguese surnames were the most frequent (from $38 \%$ in the SC to $73 \%$ in the SE) in seven of the eight mesoregions (Table IV). In the NE, however, Italian surnames predominated $(50 \%)$. Italian surnames were also the second most frequent in three other mesoregions (in the SE the frequency of $10 \%$ was the same as for German surnames). The latter were the second most common in three other cases. Again, the heterogeneity was highly significant.

There was considerable diversity in the interethnic admixture among regions (Table V). The trihybrid model did not fit the CW data, indicating little contribution from Amerindians. The calculations for this mesoregion were therefore repeated considering only European and African ancestries. This new analysis showed an African admixture of $14 \%$. In Santa Catarina, the African and Amerindian contributions were estimated as being 5\% each, lower than those estimated for Rio Grande do Sul as a whole (7 and $11 \%$, respectively). The largest African influence (12\%) was estimated for the SE, while the SW presented the highest Amerindian admixture (13\%).

Multivariate approaches were employed to analyze similarities among mesoregions based on the four data sets. $D_{A}$ genetic distances provided dissimilarity matrices for the construction of UPGMA dendrograms and three-dimensional principal coordinate diagrams. The results of these two grouping methods were generally concordant and are shown in Figures 1-4 along with corresponding maps.

Figure 1 summarizes the findings for the 17 genetic systems studied. A cluster incorporating five mesoregions (NW, MPOA, SC, NE and CE) is apparent; of the remaining regions, the most deviant is mesoregion $\mathrm{CW}$. A general northeast-southwest division is discernible. 
Table V - Estimated interethnic admixture in the European-derived populations of seven mesoregions of the State of Rio Grande do Sul (RS) and in Santa Catarina (SC).

\begin{tabular}{|c|c|c|c|c|c|c|}
\hline \multirow[t]{3}{*}{ Mesoregions $^{1}$} & \multicolumn{6}{|c|}{ Contributions } \\
\hline & \multicolumn{2}{|c|}{ European } & \multicolumn{2}{|c|}{ African } & \multicolumn{2}{|c|}{ Amerindian } \\
\hline & Mean & SE & Mean & SE & Mean & SE \\
\hline NW & 0.825 & 0.010 & 0.066 & 0.006 & 0.109 & 0.008 \\
\hline $\mathrm{NE}$ & 0.871 & 0.018 & 0.032 & 0.012 & 0.097 & 0.014 \\
\hline $\mathrm{CW}$ & 0.957 & 0.019 & 0.069 & 0.015 & -0.027 & 0.017 \\
\hline $\mathrm{CE}$ & 0.869 & 0.003 & 0.075 & 0.002 & 0.056 & 0.002 \\
\hline MPOA & 0.796 & 0.015 & 0.081 & 0.011 & 0.122 & 0.013 \\
\hline SW & 0.802 & 0.013 & 0.070 & 0.009 & 0.129 & 0.011 \\
\hline $\mathrm{SE}$ & 0.812 & 0.001 & 0.123 & 0.001 & 0.065 & 0.001 \\
\hline RS & 0.821 & 0.012 & 0.072 & 0.008 & 0.107 & 0.010 \\
\hline $\mathrm{SC}$ & 0.895 & 0.012 & 0.051 & 0.008 & 0.054 & 0.010 \\
\hline \multicolumn{7}{|c|}{ Results of the dihybrid analysis } \\
\hline $\mathrm{CW}$ & 0.856 & 0.024 & 0.144 & 0.024 & - & - \\
\hline
\end{tabular}

${ }^{1}$ Abbreviations as defined in Table II.
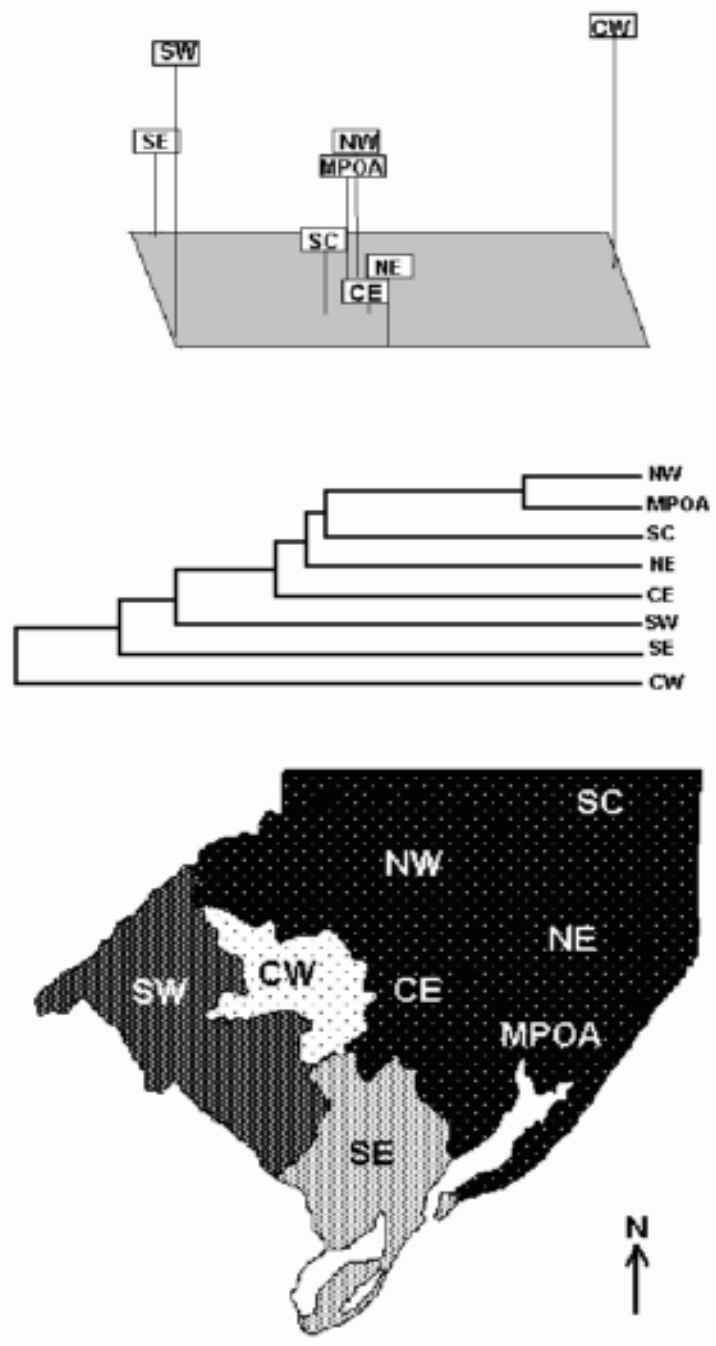

Three of the five mesoregions which clustered in the genetic distribution analysis (NW, MPOA, SC) also associated when the grandparents' nationalities were considered (Figure 2). In this case, however, mesoregion CW was included in this cluster and the most deviant mesoregion was now NE.

Two main groups were obtained when surnames were considered (Figure 3). Three of the mesoregions forming the cluster in Figure 1 (NE, NW, SC) were now separated from the other five, leading again to a northeast-southwest partition.

Finally, Figure 4 depicts the interethnic admixture. Two clusters were discernible, with mesoregion $\mathrm{CW}$ being completely isolated from both of them. One of the clusters included three of the five mesoregions grouped together in Figure 1 (NW, MPOA, NE), the other connecting $\mathrm{SC}$ with $\mathrm{CE}$ and, at a lower level, SE.

Mantel's (1967) coefficients were calculated to verify the congruence between these four sets of results (Table VI). As expected, distances based on genetic markers were correlated with those obtained using admixture estimates ( $\mathrm{r}: 0.57 ; \mathrm{P}=0.044$ ), while distances based on grandparents' nationalities correlated with those calculated for the individuals' surnames ( $\mathrm{r}: 0.61 ; \mathrm{P}=0.002)$. On the other hand, there were no significant correlations between genetics, grandparents' nationalities and individuals' surnames. A multiple Mantel's (1967) correlation coefficient comprising these three matrices was also nonsignificant (multiple r: 0.317; $\mathrm{P}=0.560$ ).

Table VII lists the seven phenotype associations between systems for which significant results were obtained at the 5\% level. Based on the number of comparisons made (52), and using a probability value of $0.1 \%$, only three of these associations (ACP/Hp, MNSs/Duffy, and $\mathrm{Rh} / \mathrm{ACP}$ ) remained significant.

\section{DISCUSSION}

The allele frequencies obtained in the present study did not differ markedly from those found by others (cited in the Introduction and Subject and Method sections) in Rio Grande do Sul and Santa Catarina or in their putative parental groups. As expected, the level of interpopulation variability observed here $\left(\mathrm{G}_{\mathrm{ST}}, 0.006\right)$ was lower than that obtained for Europe as a whole $(0.016 \pm 0.002$; CavalliSforza et al., 1994), since the geographical area considered was smaller, and the number of populations and loci examined was much less than those studied by the authors indicated above. The latter also evaluated more diversified populations.

Figure 1 - Multivariate analyses of the genetic variation: (a) principal coordinates, (b) dendrogram obtained from the $\mathrm{D}_{\mathrm{A}}$ distances, (c) map of both distributions. Shading is arbitrary, but indicates the major associations among mesoregions. 

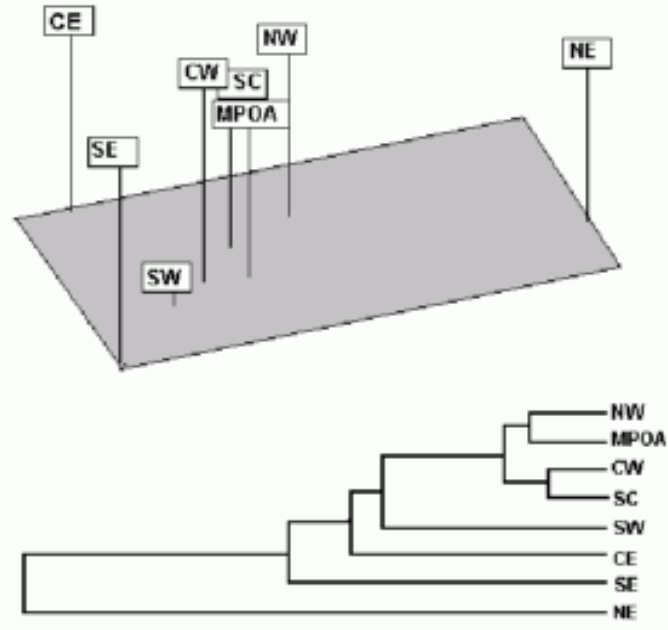

b.

a.
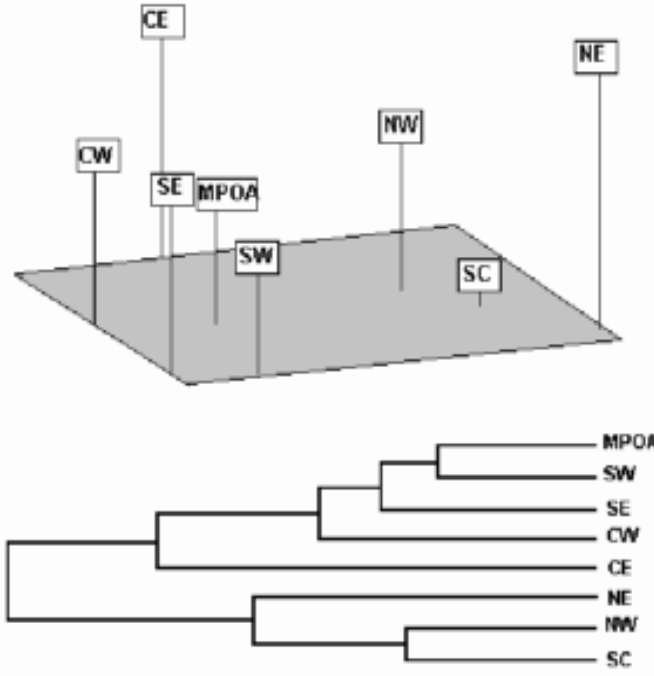

c.

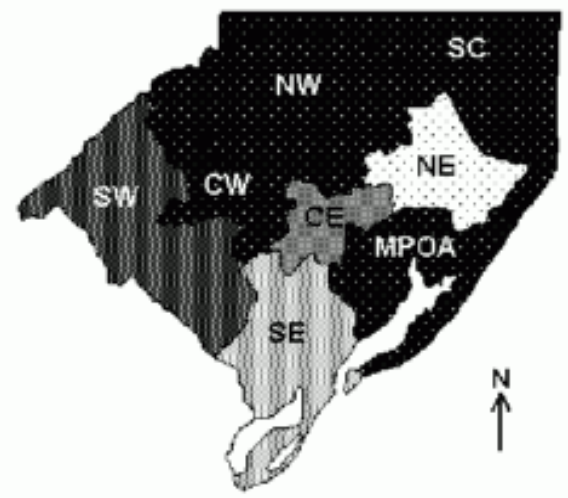

Figure 2 - Multivariate analyses of the distribution of grandparents' nationalities: (a) principal coordinates, (b) dendrogram obtained from the $\mathrm{D}_{\mathrm{A}}$ distances, (c) map of both distributions. Shading is arbitrary, but indicates the major associations among mesoregions.

The higher percentage of European contribution to the interethnic admixture in Santa Catarina (89\%) compared to Rio Grande do Sul $(82 \%)$ was expected, since the former has received a smaller number of non-Caucasian immigrants. But there are differences within Rio Grande do Sul that would also be expected on historical grounds. Thus, the lowest African admixture (3\%) was found in mesoregion $\mathrm{NE}$, an area in which the Italian contribution was most marked, while the highest (12\%) was encountered in the SE, a region in which there was a high concentration of slave labor during the colonial period (Cesar, 1972). The average Amerindian contribution for Rio Grande do Sul as a whole (11\%) was higher than expected, but the highest estimated Amerindian proportions were located in regions ( $\mathrm{SW}, \mathrm{NW}$, and coastal portion of MPOA) where historically there were higher Indian concentrations (Freitas, 1987). Salzano (1997) summarized the previous estimates of interethnic admixture found in Southern Bra- zil. For the European-derived population of Porto Alegre, the African contribution was found to be $8 \%$ (Franco et al., 1982), exactly the same value observed here for metropolitan Porto Alegre. However, no trihybrid estimates were done in the above studies, which were restricted to urban populations. As shown by Sans et al. (1997) for Uruguay, important urban/rural differences in the prevalence of interethnic crossings may exist.

Four data bases (gene frequencies, grandparents' nationalities, individuals' surnames, and interethnic admixture) were used to analyze heterogeneity in the region studied. Although there was agreement between the two types of multivariate evaluations (dendrograms and principal coordinate analysis) used for all variables, differences were found when the four sets of data were considered. The non-genetic data clearly reflected the different European contributions to the composition of these populations. The clustering of mesoregions was attributable mainly to simi- 

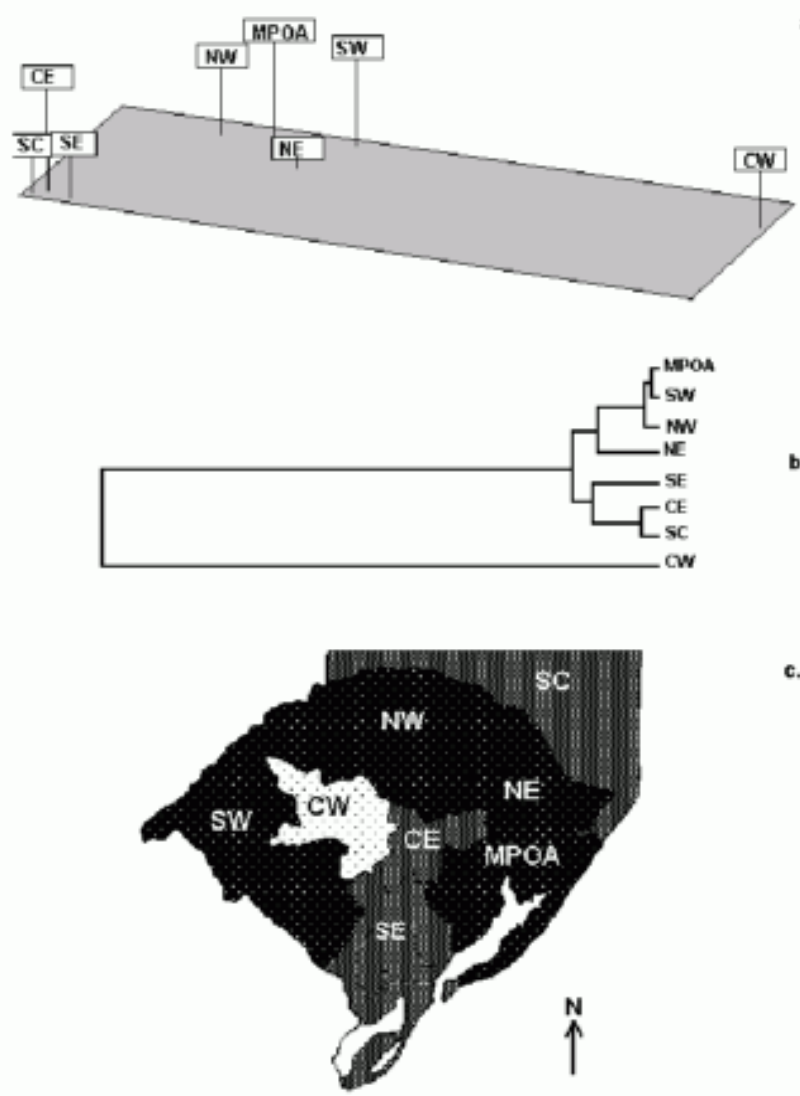

Figure 4 - Multivariate analyses of the interethnic admixture: (a) principal coordinates, (b) dendrogram obtained from the $\mathrm{D}_{\mathrm{A}}$ distances, (c) map of both distributions. Shading is arbitrary, but indicates the major associations among mesoregions.
Table VI - Agreement between distance matrices based on four sets of data obtained in Rio Grande do Sul and Santa Catarina. Upper triangle: Mantel's (1967) coefficients; lower triangle: P values.

\begin{tabular}{|lcccc|}
\hline & $\begin{array}{c}\text { Genetic } \\
\text { systems }\end{array}$ & $\begin{array}{c}\text { Grandparents' } \\
\text { nationalities }\end{array}$ & $\begin{array}{c}\text { Individuals' } \\
\text { surnames }\end{array}$ & $\begin{array}{c}\text { Interethnic } \\
\text { admixture }\end{array}$ \\
\hline $\begin{array}{l}\text { Genetic } \\
\text { systems }\end{array}$ & & 0.253 & 0.307 & 0.574 \\
$\begin{array}{l}\text { Grandparents, } \\
\text { nationalities }\end{array}$ & 0.233 & & 0.612 & -0.136 \\
$\begin{array}{l}\text { Individuals' } \\
\text { surnames }\end{array}$ & 0.130 & 0.002 & & 0.107 \\
$\begin{array}{l}\text { Interethnic } \\
\text { admixture }\end{array}$ & 0.044 & 0.476 & 0.319 & \\
\hline
\end{tabular}

larities in the frequencies of German and Italian grandparents, on one hand, and similar prevalences of Italian, Polish, and Portuguese surnames on the other. The groups obtained were in agreement with the known first settlements of immigrants to these mesoregions. The Portuguese and Spanish were the first Europeans to arrive in Rio Grande do Sul, and the frequency of grandparents with these nationalities was low, the majority already being classified as Brazilians. The more recent migration of Germans (1824) and Italians (1870) (Cesar, 1972; Flores, 1990) was well represented by the separation of the NE (colonized mainly by Italians) and CE (Germans) mesoregions. The individuals' surnames, on the other hand, indicated that the state's population was becoming more homoge-

Table VII - Phenotype associations between systems (results significant at the 5\% or lower levels).

\begin{tabular}{|c|c|c|c|c|c|}
\hline $\begin{array}{l}\text { Systems and their } \\
\text { chromosome location }\end{array}$ & $\chi^{2}$ & $\begin{array}{l}\text { Degrees } \\
\text { of freedom }\end{array}$ & $\begin{array}{l}\text { Probability } \\
\text { (P) }\end{array}$ & $\begin{array}{c}\text { Corrected } \\
\text { significance }^{1}\end{array}$ & $\begin{array}{l}\text { Phenotypes with } \\
\text { highest associations }\end{array}$ \\
\hline \multirow{2}{*}{ (9) ABO/GLO1 (6) } & \multirow{2}{*}{18.17} & \multirow{2}{*}{10} & \multirow{2}{*}{0.052} & \multirow[b]{2}{*}{ NS } & $\mathrm{O} / 1-1$ \\
\hline & & & & & $\mathrm{A} 1 / 2-1$ \\
\hline \multirow{2}{*}{ (2) $\mathbf{A C P} / \mathbf{H p}$ (16) } & \multirow{2}{*}{285.41} & \multirow{2}{*}{10} & \multirow{2}{*}{$<0.001^{2}$} & \multirow{2}{*}{$\mathrm{S}$} & $\mathrm{A} / 1-1$ \\
\hline & & & & & $\mathrm{B} / 2-1$ \\
\hline (2) ACP/Duffy (1) & 11.03 & 5 & 0.051 & NS & $\mathrm{AB} / \mathrm{Fya}$ \\
\hline (22) P/Duffy (1) & 7.96 & 1 & 0.005 & NS & $\mathrm{P}+/ \mathrm{Fya}$ \\
\hline \multirow{2}{*}{ (4) MNSs/Duffy(1) } & \multirow{2}{*}{32.25} & \multirow{2}{*}{8} & \multirow{2}{*}{$<0.001$} & \multirow{2}{*}{$\mathrm{S}$} & MNSs/Fya \\
\hline & & & & & Ms/Fya- \\
\hline \multirow{2}{*}{ (4) $\mathbf{M N S s} / \mathbf{P}$ (22) } & \multirow{2}{*}{22.26} & \multirow{2}{*}{8} & \multirow{2}{*}{0.004} & \multirow{2}{*}{ NS } & $\mathrm{MSs} / \mathrm{P}$ \\
\hline & & & & & NS/P- \\
\hline \multirow{2}{*}{ (1) $\mathbf{R h} / \mathbf{A C P}$ (2) } & \multirow{2}{*}{105.85} & \multirow{2}{*}{52} & \multirow{2}{*}{$0.001^{2}$} & \multirow{2}{*}{$S$} & $\mathrm{DcEe} / \mathrm{BC}$ \\
\hline & & & & & dce/AB \\
\hline
\end{tabular}

${ }^{1}$ Significance corrected relative to the number of comparisons made (52). NS: Nonsignificant; S: significant. ${ }^{2} \chi^{2}$ by Roff and Bentzen's (1989) method. 
neous, still reflecting, however, the effect of more recent European migrations (Polish, among others).

The history told by social data is not completely matched by the genetic results. This may reflect the fact that the genetic markers used are too similar within Europe to detect the different capabilities of the derived ethnic and social groups to intercross, or to assess the length of time they have coexisted in a region. The only generalization possible is that of a distinction between the northern regions of Rio Grande do Sul and Santa Catarina, and the southern and western of Rio Grande do Sul. It is, however, noteworthy that despite the intense migratory flux that occurs in the whole area, we still have been able to detect this subdivision, which is probably a reflection of past settlements.

For the phenotype associations, nine previous studies (Shreffler et al., 1971; Sinnock and Sing, 1972a,b; Brackenridge et al., 1975; Rasmuson et al., 1979; Mohan Raj et al., 1990; Engrácia et al., 1991; Hatagima and Krieger, 1994; Fañanás et al., 1997) may be compared with the present one. Only three of the seven associations which were significant at the 5\% level in our study were also found by the above authors. Two of these, MNSs/Duffy and $\mathrm{Rh} / \mathrm{ACP}$, showed a particularly strong association ( $\mathrm{P}$ $\leq 0.001$ ) here and were also observed by Rasmuson et al. (1979) and Engrácia et al. (1991), respectively. The remaining association (P/Duffy; P:0.005) was also observed by Shreffler $e$ al. (1971), although further analyses in the same population (Sinnock and Sing, 1972a,b) yielded conflicting results.

Since in all cases the systems involved are localized in different chromosomes, we can only speculate about the reasons for these associations. Population heterogeneity cannot explain these findings, since no significant genetic differences were observed among mesoregions. The remaining possibility is selective interaction, but there are as yet no specific physiological or biochemical indications in this direction. This is a subject worth further investigation.

\section{ACKNOWLEDGMENTS}

We thank Dr. Maria Cátira Bortolini for helpful suggestions and for supplying population data and Clenio D. Machado for laboratory assistance. This work was financed by the Programa de Apoio a Núcleos de Excelência (PRONEX), Financiadora de Estudos e Projetos (FINEP), Conselho Nacional de Desenvolvimento Científico e Tecnológico (CNPq) and Fundação de Amparo à Pesquisa do Estado do Rio Grande do Sul (FAPERGS).

\section{RESUMO}

Uma amostra de 2.708 descendentes de europeus que vivem no Rio Grande do Sul, o qual foi subdividido em sete mesorregiões, e de 226 pessoas da mesma procedência provenientes de Santa Catarina foi estudada quanto a 17 sistemas genéticos protéicos, nacionalidades dos avós, sobrenomes dos indivíduos e mistura interétnica. Não foram encontradas diferenças significantes entre as mesorregiões, os alelos que apresentaram a maior e a menor diferença sendo GLO1*2 (16\%) e PGD*A (2\%), respectivamente. Os valores observados foram os esperados para descendentes de europeus, a maior diferença sendo uma menor prevalência do alelo $\mathbf{P} * \mathbf{1}$ (34-39\%). Por outro lado, foi encontrada heterogeneidade significante entre mesorregiões em relação às outras variáveis consideradas, a qual foi consistente com dados históricos. A contribuição ameríndia estimada para o conjunto gênico de descendentes de europeus da população do Rio Grande do Sul foi tão alta quanto $11 \%$. O resultado mais geral obtido, considerando os quatro conjuntos de dados, foi o de uma tendência de divisão nordeste-sudoeste para as populações estudadas. Sete associações fenotípicas significativas entre sistemas foram obtidas a nível de 5\% (três a nível de $0.1 \%$ ). Duas destas foram também observadas por outros autores: MNSs/Duffy e Rh/ACP.

\section{REFERENCES}

Anonymous (1992). SPSS Base System Syntax Reference Guide. Release 5.0. SPSS Inc., Chicago.

Arai, K., Huss, K., Madison, J., Putnam, F.W., Salzano, F.M., Franco, M.H.L.P., Santos, S.B. and Freitas, M.J.M. (1989). Amino acid substitutions in albumin variants found in Brazil. Proc. Natl. Acad. Sci. USA 86: 1821-1825.

Blake, N.M. and Omoto, K. (1975). Phosphoglucomutase types in the AsianPacific area: a critical review including new phenotypes. Ann. Hum. Genet. 38: 251-273

Bortolini, M.C., Weimer, T.A., Franco, M.H.L.P., Salzano, F.M., Layrisse, Z., Schneider, H., Schneider, M.P.C. and Harada, M.L. (1992). Genetic studies in three South American black populations. Gene Geogr. 6: 1-16.

Bortolini, M.C., Weimer, T.A., Salzano, F.M., Callegari-Jacques, S.M., Schneider, H. and Layrisse, Z. (1994). The ethnic origin of South American blacks: an estimate using genetic data. Antropol. Biol. 2: 53-62.

Bortolini, M.C., Weimer, T.A., Salzano, F.M., Callegari-Jacques, S.M., Schneider, H., Layrisse, Z. and Bonato, S. (1995). Evolutionary relationships between black South American and African populations. Hum. Biol. 67: 547-559.

Bortolini, M.C., Weimer, T.A., Salzano, F.M., Moura, L.B. and Silva, M.C.B.O. (1997a). Genetic structure of two urban Afro-Brazilian populations. Int. J. Anthropol. 12: 5-16.

Bortolini, M.C., Salzano, F.M., Zago, M.A., Silva-Junior, W.A. and Weimer, T.A. (1997b). Genetic variability in two Brazilian ethnic groups: a comparison of mitochondrial and protein data. Am. J. Phys. Anthropol. 103: 147-156.

Bortolini, M.C., Silva-Junior, W.A., Weimer, T.A., Zago, M.A., Guerra, D.C., Schneider, M.P.C., Layrisse, Z., Castellano, H.M. and Salzano, F.M. (1998). Protein and hypervariable tandem repeat diversity in eight African-derived South American populations: inferred relationships do not coincide. Hum. Biol. 70: 443-461.

Bowman, B.H. and Bearn, A.G. (1965). The presence of subunits in the inherited group-specific protein of human serum. Proc. Nat. Acad. Sci. USA 53: 722-729.

Boyd, W.C. and Shapleigh, E. (1954). Diagnosis of subgroups of blood groups $\mathrm{A}$ and $\mathrm{AB}$ by use of plant agglutinins (lectins). J. Lab. Clin. Med. 44: 235-237.

Brackenridge, C.J., Case, J. and Sheehy, A.J. (1975). Distributions, sex and age effects, and joint associations between phenotypes of 14 genetic systems in an Australian population sample. Hum. Hered. 25: 520-529.

Cavalli-Sforza, L.L., Menozzi, P. and Piazza, A. (1994). History and Geography of Human Genes. Princeton University Press, Princeton.

Cesar, G. (1972). História do Rio Grande do Sul. Período Colonial. Editora Globo, Porto Alegre.

Chakraborty, R. (1985). Gene identity in racial hybrids and estimation of 
admixture rates. In: Genetic Differentiation in Human and other Animal Populations (Ahuja, Y.R. and Neel, J.V., eds.). Indian Anthropological Association, Delhi, pp. 171-180.

Dunsford, I. and Bowley, C.C. (1967). Techniques in Blood Grouping. Oliver and Boyd, London.

Engrácia, V., Mestriner, M.A., Cabello, P.H. and Krieger, H. (1991). Association between the acid phosphatase 1 and adenosine deaminase systems in a Brazilian sample. Hum. Hered. 41: 147-150.

Fañanás, L., Sala, J., Vives, S. and Moral, P. (1997). Pairwise associations between classical polymorphisms in a human population from the Central Pyrenees. Int. J. Anthropol. 12: 49-54.

Fildes, R.A. and Harris, H. (1966). Genetically determined variation of adenylate kinase in man. Nature 209: 261-263.

Fildes, R.A. and Parr, C.W. (1963). Human red-cell phosphogluconate dehydrogenases. Nature 200: 890-891.

Flores, M. (1990). História do Rio Grande do Sul. 3rd edn. Nova Dimensão, Porto Alegre.

Franco, M.H.L.P. and Salzano, F.M. (1985). A comparative study of albumin variants found in Brazil. Hum. Hered. 35: 34-38.

Franco, M.H.L.P., Salzano, F.M. and Maia de Lima, F.A. (1981). Blood groups and serum protein types in two Brazilian populations. Rev. Bras. Genét. 4: 689-704.

Franco, M.H.L.P., Weimer, T.A. and Salzano, F.M. (1982). Blood polymorphisms and racial admixture in two Brazilian populations. Am. J. Phys. Anthropol. 58: 127-132.

Franco, M.H.L.P., Moreira, D.M., Salzano, F.M., Santos, S.E.B., Conceição, M.M. and Schneider, H. (1986). New data on the association between the glyoxalase I and haptoglobin loci. Hum. Hered. 36: $126-128$

Franco, M.H.L.P., Brennan, S.O., Chua, E.K.M., Kragh-Hansen, U., Callegari-Jacques, S.M., Bezerra, M.Z.P.J. and Salzano, F.M. (1998). Albumin genetic variability in South America: population distribution and molecular studies. Am. J. Hum. Biol. 11: 359-366.

Freitas, S.M.R. (1987). Estudos Rio-Grandenses. 2nd edn. Sagra, Porto Alegre.

Gahlinger, P.M. and Abramson, J.H. (1995). PEPI: Computer Programs for Epidemiologic Analysis. Version 2. USD, Stone Mountain, USA.

Geserick, G., Bundschuh, G. and Rose, M. (1968). Zur technik der Transferrintypen-bestimmung. Arztl. Lab. 14: 507-512.

Harris, H. and Hopkinson, D.A. (1976). Handbook of Enzyme Electrophoresis in Human Genetics. North-Holland Publishing Co., Amsterdam.

Hatagima, A. and Krieger, H. (1994). Studies on polymorphism segregation in northeastern Brazil. I. Analysis of multiloci. Rev. Bras. Genét. 17: 431-434

Hedges, S.B. (1992). The number of replications needed for accurate estimation of the bootstrap $\mathrm{P}$ value in phylogenetic studies. Mol. Biol. Evol. 9: 366-369.

Heidrich, E.M., Hutz, M.H., Salzano, F.M., Coimbra Jr., C.E.A. and Santos, R.V. (1995). D1S80 locus variability in three Brazilian ethnic groups. Hum. Biol. 67: 311-319.

Hutz, M.H., Yoshida, A. and Salzano, F.M. (1977). Three rare G-6-PD variants from Porto Alegre, Brazil. Hum. Genet. 39: 191-197.

IBGE (1991). Censo Demográfico 1991. Características Gerais da População e Instrução. Rio Grande do Sul. No. 24. Fundação Instituto Brasileiro de Geografia e Estatística, Rio de Janeiro.

Kueppers, E. and Bearn, A.G. (1966). Inherited variation of human serum alpha-1-antitrypsin. Science 154: 407-408.

Lewgoy, F. and Salzano, F.M. (1968). G-6-PD deficiency gene dynamics in a Brazilian population. Acta Genet. Med. Gemellol. 17: 595-606.

Mantel, N. (1967). The detection of disease clustering and a generalized regression approach. Cancer Res. 27: 209-220.

Mohan Raj, B.K., Damodaran, C. and Chandra Sekharan, P. (1990). Studies of association between some genetic systems (ABO, MN, ESD, GLO, C3 and Hp). Hum. Hered. 40: 190-192.

Mourant, A.E., Kopec, A.C. and Domaniewska-Sobczak, K. (1976). The Distribution of the Human Blood Groups and other Polymorphisms. Oxford University Press, Oxford.

Nei, M. (1973). Analysis of gene diversity in subdivided populations. Proc. Nat. Acad. Sci. USA 70: 3321-3323.

Nei, M. (1986). Definition and estimation of fixation indices. Evolution 40 :
643-645

Nei, M. (1987). Molecular Evolutionary Genetics. Columbia University Press, New York.

Nei, M. and Roychoudhury, A.R. (1993). Evolutionary relationships of human populations on a global scale. Mol. Biol. Evol. 10: 927-943.

Nei, M., Tajima, F. and Tateno, Y. (1983). Accuracy of estimated phylogenetic trees from molecular data. II. Gene frequency data. J. Mol. Evol. 19: $153-170$

Ota, T. (1993). DISPAN: Genetic Distance and Phylogenetic Analysis. University Park, Institute of Molecular Evolutionary Genetics, Pennsylvania State University, Pennsylvania.

Parr, C.W., Baster, J.A. and Welch, S.G. (1977). Human red cell glyoxalase I polymorphism. Biochem. Genet. 15: 105-113.

Poulik, M.D. (1957). Starch gel electrophoresis in a discontinuous system of buffers. Nature 180: 1477-1479.

Rasmuson, M., Heiken, A. and Swan, T. (1979). The occurrence of interlocus disequilibrium in combinations of genetic marker systems in man. Hereditas 91: 279-293.

Reed, T.E. and Schull, W.J. (1968). A general maximum likelihood method estimation program. Am. J. Hum. Genet. 20: 579-580.

Rieger, T.T., Weimer, T.A., Salzano, F.M., Franco, M.H.L.P. and Moreira, D. (1988). ESD, ACP and GLO frequencies in southern Brazil, with a note on heterozygosity levels. Rev. Bras. Genét. 11: 155-163.

Robinson, W.M., Dorneles, C.L., Salzano, F.M., Hickmann, A.C., Weimer, T.A., Franco, M.H.L.P. and Geiger, C.J. (1998). Genetic similarity and mate selection in Brazil. Ciênc. Cult. 50: 291-293.

Roff, D.A. and Bentzen, P. (1989). The statistical analysis of mitochondrial DNA polymorphism: $\chi^{2}$ and the problem of small samples. Mol. Biol. Evol. 6: 539-545.

Rohlf, F.J. (1987). NTSYS-pc. Numerical Taxonomy and Multivariate Analysis System for the IBM PC Microcomputer (and Compatibles). Applied Biostatistics Inc., Setauket.

Roychoudhury, A.K. and Nei, M. (1988). Human Polymorphic Genes. World Distribution. Oxford University Press, Oxford.

Salzano, F.M. (1963). Blood groups and gene flow in Negroes from southern Brazil. Acta Genet. Basel. 13: 9-20.

Salzano, F.M. (1997). Human races: myth, invention, or reality? Interciencia 22: $221-227$

Salzano, F.M., Suñé, M.V. and Ferlauto, M. (1967). New studies on the relationship between blood groups and leprosy. Acta Genet. Basel. 17: $530-544$.

Salzano, F.M., da Rocha, F.J. and Tondo, C.V. (1968a). Hemoglobin types and gene flow in Porto Alegre, Brazil. Acta Genet. Basel. 18: 449457.

Salzano, F.M., Lewgoy, F., Tondo, C.V. and da Rocha, F.J. (1968b). G6PD deficiency and abnormal hemoglobins in a Brazilian population. Acta Genet. Med. Gemellol. 17: 607-612.

Salzano, F.M., Callegari-Jacques, S.M., Weimer, T.A., Franco, M.H.L.P., Hutz, M.H. and Petzl-Erler, M.L. (1997). Electrophoretic protein polymorphisms in Kaingang and Guarani Indians of southern Brazil. Am. J. Hum. Biol. 9: 505-512.

Sans, M., Salzano, F.M. and Chakraborty, R. (1997). Historical genetics in Uruguay: estimates of biological origins and their problems. Hum. Biol. 69: 161-170.

Schwantes, A.R., Salzano, F.M., Castro, I.V. and Tondo, C.V. (1967). Haptoglobins and leprosy. Acta Genet. Basel. 17: 127-136.

Shreffler, D.C., Sing, C.F., Neel, J.V., Gershowitz, H. and Napier, J.A. (1971). Studies on genetic selection in a completely ascertained Caucasian population. I. Frequencies, age and sex effects, and phenotype associations for 12 blood group systems. Am. J. Hum. Genet. 23: 150-163

Silva, R.S., Weimer, T.A. and Salzano, F.M. (1981). Rare and common types of phosphoglucomutase in two Brazilian populations. Hum. Biol. 53: 227-238

Sinnock, P. and Sing, C.F. (1972a). Analysis of multilocus genetic systems in Tecumseh, Michigan. I. Definition of the data set and tests for goodness-of-fit to expectations based on gene, gamete, and singlelocus phenotype frequencies. Am. J. Hum. Genet. 24: 381-392.

Sinnock, P. and Sing, C.F. (1972b). Analysis of multilocus genetic systems in Tecumseh, Michigan. II. Consideration of the correlation between nonalleles in gametes. Am. J. Hum. Genet. 24: 393-415. 
Sneath, P.H.A. and Sokal, R.R. (1973). Numerical Taxonomy. W.H. Freeman, San Francisco.

Spencer, N., Hopkinson, D.A. and Harris, H. (1964). Phosphoglucomutase polymorphism in man. Nature 21: 742-745.

Spencer, N., Hopkinson, D.A. and Harris, H. (1968). Adenosine deaminase polymorphism in man. Ann. Hum. Genet. 32: 9-14.

Tills, D., Kopec, A.C. and Tills, R.E. (1983). The Distribution of the Human Blood Groups and other Polymorphisms. Supplement 1. Oxford University Press, Oxford.

Tondo, C.V. and Salzano, F.M. (1962). Abnormal hemoglobins in a Brazilian Negro population. Am. J. Hum. Genet. 14: 401-409.

Tondo, C.V., Mundt, C. and Salzano, F.M. (1963). Haptoglobin types in Brazilian Negroes. Ann. Hum. Genet. 26: 325-331.

Weimer, T.A., Salzano, F.M. and Hutz, M.H. (1981). Erythrocyte isozymes and hemoglobin types in a southern Brazilian population. J. Hum. Evol. 10: 319-328.

Weimer, T.A., Rieger, T.T. and Salzano, F.M. (1987). Occurrence of a rare variant of superoxide dismutase in Brazil. Hum. Hered. 37: 26-29.

Weimer, T.A., Salzano, F.M., Westwood, B. and Beutler, E. (1993). Molecular characterization of glucose-6-phosphate dehydrogenase variants from Brazil. Hum. Biol. 65: 41-47.

Weimer, T.A., Salzano, F.M., Westwood, B. and Beutler, E. (1998). G6PD variants in three South American ethnic groups: population distribution and description of two new mutations. Hum. Hered. 48: 92-96.

Weitkamp, L.R., Shreffler, D.C., Robbins, J.L., Drachmann, O., Adner P.L., Wieme, R.J., Simon, N.M., Cooke, K.B., Sandor, G., Wuhrmann, F., Braend, M. and Tarnoky, A.L. (1967). An electrophoretic comparison of serum albumin variants from nineteen unrelated families. Acta Genet. Basel. 17: 399-405.

Yuasa, F., Ikebuchi, J., Suenaga, K. and Ito, K. (1986). Phosphoglucomutase 1 subtypes: polymorphic occurrence of $\mathrm{PGM}^{*} 7+$ and geographical variation in Japan. Hum. Hered. 36: 233-237.

(Received July 25, 1998) 
